\title{
Terranes and Continental Accretion in the Colombian Andes
}

\author{
by Jorge J. Restrepo and Jean F. Toussaint
}

The northwestern corner of South America is composed of a mosaic of terranes accreted to the Guiana Shield at various times in the late Paleozoic(?), Early Cretaceous, Late Cretaceous and Middle Miocene. The eastern terranes possess a continental basement whereas those to the west are fundamentally oceanic. This contribution from IGCP Project 279 ("Terranes in Latin America") describes the main lithostratigraphic and structural features of the various exotic terranes, as well as their borders and the timing of accretionary events. (Ed.)

\section{Introduction}

Recent work in the Colombian Andes has demonstrated the existence of several geological provinces that may represent terranes accreted to the northwestern border of the Guiana Shield (Case et al., 1971; Forero, 1986; Aspden and McCourt, 1985; Toussaint and Restrepo, 1986; Etayo-Serna et al., 1983; Toussaint et al., 1987). The eastern Andean region of Colombia has a continental basement, and its geology is basically different to that of the western Andean region, which is underlain by oceanic crust. The boundary between these regions is a fundamental suture that extends from the Sierra Nevada de Santa Marta (SNSM) to Ecuador (Fig. 1). Each of these regions is formed by several exotic terranes, described in the following.

\section{The Autochthonous Block}

The region east of the Andes, including the Llanos (Fig. 1) and the Amazonas region, has been part of the Guiana Shield since at least the beginning of Paleozoic times. In this sense the region is an autochthonous block. The Precambrian basement (Fig. 2) is composed mainly by the Mitu Migmatitic Complex and the Garzon Granulitic Group, which yield radiometric ages between 1800 and $1180 \mathrm{Ma}$. After the Precambrian structural and metamorphic events, the basement was cut by $\mathrm{NW}$-trending faults, forming blocks tilted to the west. On the western border, unmetamorphosed platform sediments were deposited during Cambrian(?) and Ordovician times. Following the accretion of the Eastern Andean Terrane (EAT), these sediments were unconformably covered by Jurassic continental sediments and by Cretaceous marine sediments (Figs. 2 and 3 ). Beneath the Mesozoic cover, the Paleozoic platform sediments were slightly folded.

\section{Terranes with Continental Crust}

Terranes with continental crust are found between the Guaicaramo-Santamaria-Yopal fault system, which forms the limit between the Andes and the Llanos, and the CaucaRomeral fault system, located between the Central and the Western Cordillera (Fig. 2). The continental crust reaches here a thickness of $33-45 \mathrm{~km}$, with negative Bouguer anomalies that range from $-100 \mathrm{mgal}$ over the axis of the Central Cordillera, to $-30 \mathrm{mgal}$ in the Magdalena Valley and up to $-180 \mathrm{mgal}$ in the Eastern Cordillera (Bermudez et al., 1985).
Two terranes can be distinguished in this zone (Fig. 4). The EAT includes the structural units of the Cesar Valley, Serranía de Perijá, Santander Massif, Magdalena Valley, Eastern Cordillera and the majority of the SNSM. The Central Andean Terrane (CAT) comprises the western and central parts of the northern Central Cordillera (Fig. 1).

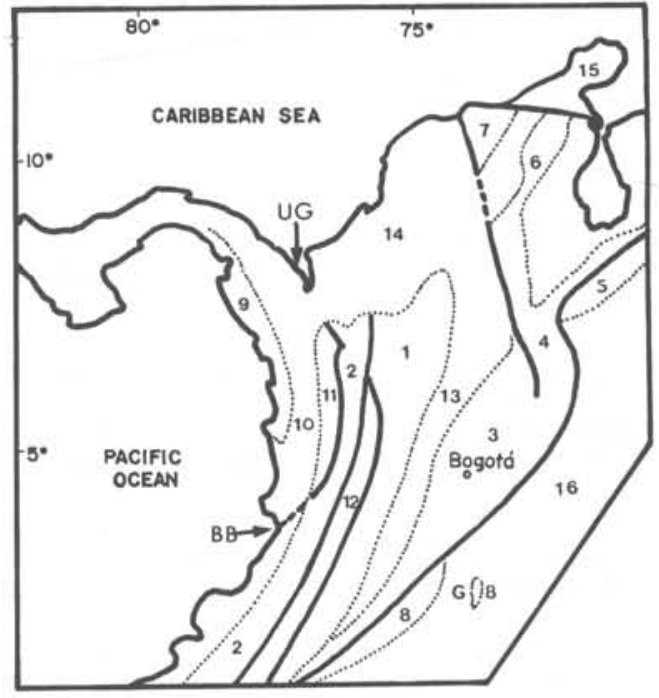

Figure 1: Physiographic map of Colombia and adjacent regions. 1: Central Cordillera, 2: Western Cordillera, 3: Eastern Cordillera, 4: Santander Massif, 5: Merida Andes, 6: Serranía de Perijá, 7: Sierra Nevada de Santa Marta (SNSM), 8: Sierra de la Macarena and Garzón Massif (G), 9: Serranía de Baudó, 10: Atrato Valley, 11: Mandé Arch, 12: Cauca valley, 13: Magdalena and Cesar valleys, 14: Caribbean coastal lowlands, 15: La Guajira Peninsula, 16: Llanos. UG - Uraba Gulf, BB - Bonaventura Bay.

The Eastern Andean Terrane is formed by Precambrian metamorphic basement that crops out in SNSM, Santander Massif and the eastern border of the Central Cordillera. It is overlain unconformably by low to medium-grade metamorphic rocks in Serranía de Perijä, Santander Massif and Quetame Massif (Fig. 2). These rocks were metamorphosed before Devonian times, for they are covered by unmetamorphosed epicontinental sediments of Devonian and Carboniferous age.

The lower Mesozoic is a supra-terrane that was deposited unconformably over the Paleozoic sediments. It consists mainly of thick continental Jurassic red beds locally asso- 
ciated with acidic to basic pyroclastics and flows. These rocks are referred to locally as the Saldaña Formation in the upper Magdalena Valley, the Giron Formation in the central Magdalena Valley and the La Quinta Formation in Serranía de Perijá.

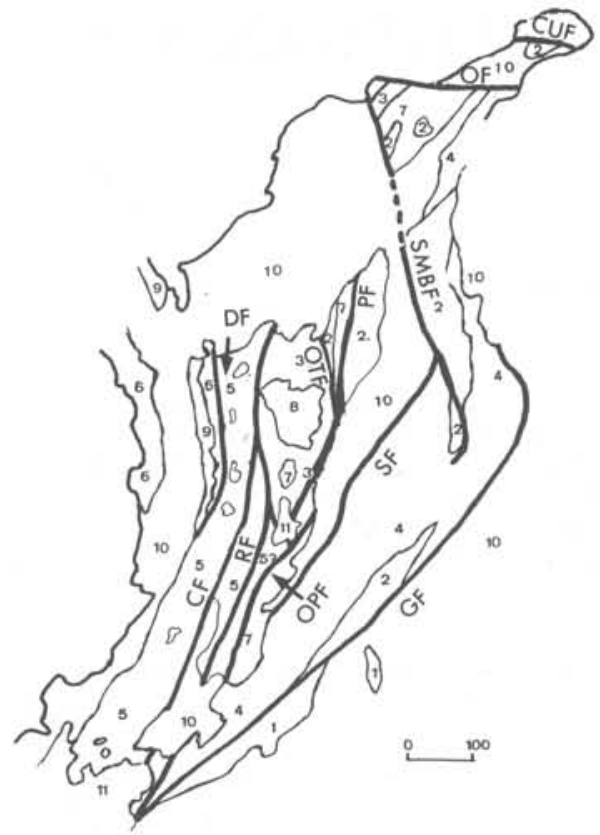

Figure 2: Simplified geological map of the Colombian Andes. 1: Precambrian metamorphic basement of the autochthonous block, 2: Precambrian and lower Paleozoic metamorphic basement of the EAT, 3: Polymetamorphic basement of the CAT, 4: Mesozoic sediments of the EAT, 5: Cretaceous basic volcanic and sedimentary rocks of the WAT, 6: Cretaceous and Cenozoic basic volcanics of the PBMT, 7: Jurassic plutonism, 8: Cretaceous plutonism, 9: Cenozoic plutonism, 10: Cenozoic sediments, 11: P1iocene to Quaternary volcanism. CF: Cauca Fault, CUF: Cuisa Fault, DF: Dabeiba Fault, GF: Guaicaramo Fault, OF: Oca Fault, OPF: Otu-Pericos Fault, PF: Palestina Fault, RF: Romeral Fault, SF: Salinas Fault, SMBF: Santa Marta-Bucaramanga Fault.
The western side of the EAT was affected during Jurassic times by extensive granodioritic to tonalitic plutonism that forms an almost continuous north-south belt for more than $1000 \mathrm{~km}$ from Ecuador to the SNSM (Figs. 2 and 3). A very important marine transgression during Early Cretaceous times affected the EAT and the autochthonous rocks to the east. The Central Andean Terrane also suffered a marine transgression at this time, but it is not certain that the two terranes were yet welded together.

The EAT was affected by Precambrian metamorphic events and an important Caledonian Orogeny accompanied by a metamorphic event that was the last one in this terrane. Hercynian tectonogenesis was very slight and marked only by small angular unconformities. After the accretion of the EAT to the autochthonous block, the former was affected mainly by tensional movements during the Mesozoic, probably related to the opening of the Caribbean or to the formation of a back-are basin along the Magdalena and Cesar valleys.

The Central Andean Terrane is mainly represented by a polymetamorphic complex in the northern part of the Central Cordillera (Fig. 2). In it, several metamorphic events have been recognized (Fig. 3). A Precambrian metamorphism has been postulated for several high-grade zones but has not been confirmed radiometrically. Two Paleozoic events have been documented; one of Devonian age has been detected by $\mathrm{Rb} / \mathrm{Sr}$ isochrons on orthogneisses, and the other of Permian to Triassic age has been dated by some $\mathrm{Rb} / \mathrm{Sr}$ isochrons and by abundant $\mathrm{K} / \mathrm{Ar}$ datings (Restrepo and Toussaint, 1982).

Pre-Cretaceous sediments are absent from the CAT, including the conspicuous Jurassic red beds so typical of the EAT. Early Cretaceous marine sediments were deposited over the metamorphic complex though, as noted before, it is not certain if they correlate with those on the EAT. Large tonalitic batholiths of Late Cretaceous age intrude the suture between the Western and Central Andean terranes.

The CAT was also affected during mid-Cretaceous time by an important tectogenesis related to the suturing of the WAT on its western side. This involved significant overthrusting of oceanic rocks. Later, during the Late Cretaceous and Cenozoic, important wrench faulting took place on both the western side of the CAT along the Cauca-Romeral system and on the eastern side along the Palestina fault.

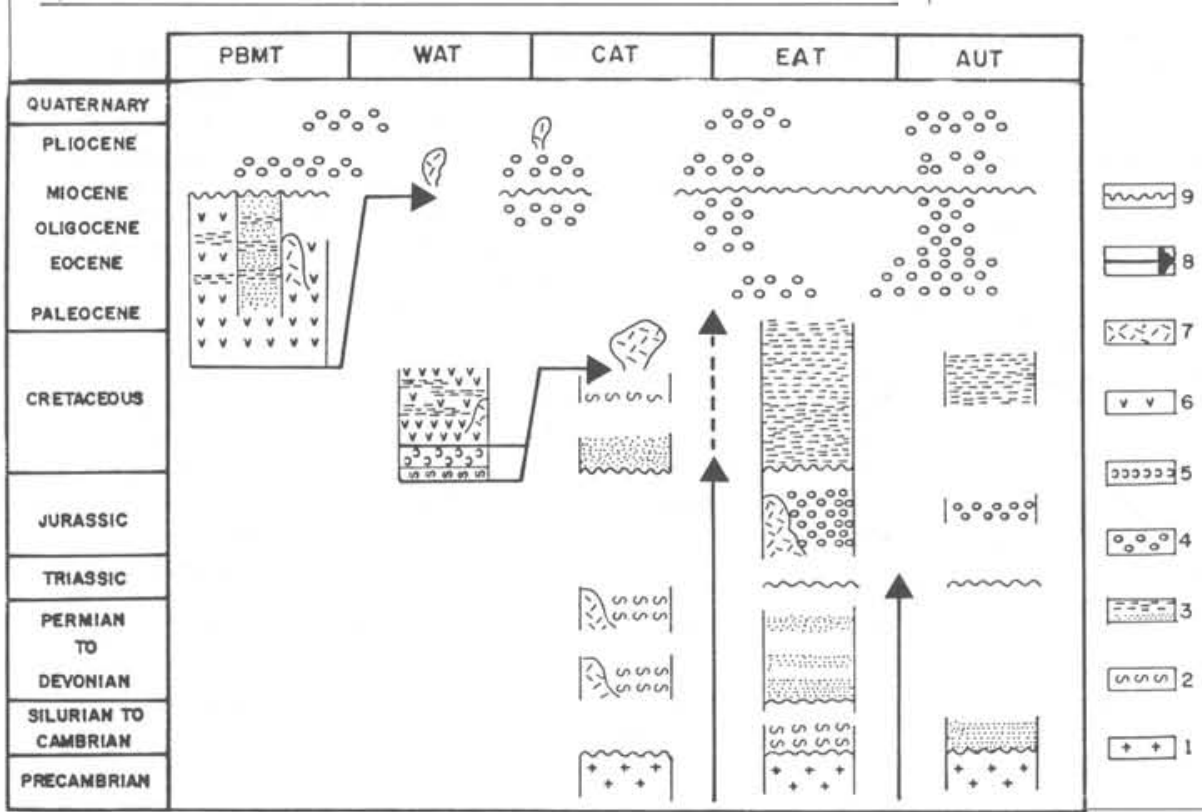

\section{Terranes with Oceanic Basement}

To the west of the CAT and in places overlapping its western side, lithological units that represent oceanic rocks are found. Two terranes can now be distinguished here: the Western Andean Terrane (WAT), which represents oceanic crust and island ares of Tethyan origin accreted to the continental CAT during Cretaceous times, and the Panama-Baudo-Mandé Terrane (PBMT) comprising oceanic erust and island ares accreted to the WAT during Miocene times (Fig. 2, 3 and 4).

Figure 3: Generalized stratigraphic columns and successive sutures in Colombia. 1: Precambrian basement, 2: metamorphic event, 3: marine sedimentation, 4: continental sedimentation, 5: ophiolites, 6: basic volcanism, 7: granitoid plutonism, 8: suture, 9: main unconformities. 
The Western Andean Terrane is separated from the CAT to the east by a suture defined by obducted ophiolites. To the west, the suture is marked by the Dabeiba fault that probably corresponds to an overthrusting of the margin of the PBMT onto the edge of the WAT, on the western flank of the Western Cordillera (Figs. 4 and 5). According to Case and others (1971) and Flueh and co-workers (1981) the Moho can be located here at a depth of about $30 \mathrm{~km}$, with seismic velocities indicating oceanic material, and Bouguer anomalies of $-50 \mathrm{mgal}$ on the western side and $-80 \mathrm{mgal}$ in the Cauca Valley.

The WAT is composed mainly by mafic and ultramafic rocks associated with cherts, limestones and turbidites (Fig. 3). Medium to high pressure metamorphic rocks crop out along the suture with the CAT. In the central and southern Western Cordillera the sedimentary rocks of the Dagua Group were converted to slates and phyllites during Late Cretaceous time. Tholeiitic basalts, with abundant pillow-lavas, are included in the Diabase Group. Local fossiliferous intercalations yield ages in the range Early Cretaceous to early Senonian. Radiometric ages of the basalts are distributed in two groups, one in the range 105-97 Ma seems to correspond to the igneous age, while the other between 83-68 Ma seems to be dating the low grade metamorphic event.

In the northern Western Cordillera, the Cretaceous rocks are included in the Cañasgordas Group, which is subdivided into the Barroso Formation for the basaltic rocks and the Penderisco Formation for the flysch and pelagic rocks. The sequence is believed to range from Aptian-Albian to Senonian. On the eastern border of the WAT, both in the Cauca depression and in the western flank of the Central Cordillera (Fig. 1), Cretaceous mafic and ultramafic rocks crop out, having been grouped in several ophiolitic complexes, such as Cauca, Bolivar and Los Azules complexes. They probably correspond to oceanic crust, together with part of the basalts, although immature ares may well have existed in several places.

High to medium-pressure metamorphic rocks are found mostly on the western flank of the Central Cordillera. Amphibolites, greenschists and mica schists are the more common rocks, and they have yielded radiometric ages between 117 and $90 \mathrm{Ma}$. The high-pressure rocks are represented by ecologites and blueschists with radiometric ages in the range $125-10 \mathrm{Ma}$. The emplacement of the mafic and ultramafic rocks, as well as the equivalent metamorphic rocks, was accomplished by a thrusting to the east over the continental basement (Restrepo and Toussaint, 1974). In the central Western Cordillera the structure has been interpreted as a complex sequence of nappes (Bourgois et al., 1982).

The Panamá-Baudó-Mandé Terrane (PBMT, Fig. 2) is composed of three structural elements: the western flank of the Western Cordillera (corresponding to the Mande igneous complex), the Atrato-San Juan basin, and the Serranía de Baudo (Fig. 1). These structures continue into Panama. An important characteristic of the PBMT is the presence of two gravity highs corresponding to Baudó (to $90 \mathrm{mgal}$ ) and Mandé (130 mgal), separated by a gravity low $(-70 \mathrm{mgal})$ in the Atrato-San Juan basin (Case et al., 1971). The Moho is located here at a depth of about $30 \mathrm{~km}$ (Flueh et al., 1981). The PBMT corresponds to a block of oceanic crust beneath a magmatic arc, which formed somewhere in the Pacific Ocean and then collided with northwestern South America. The gravity high may be due to the tectonic uplift of this block.

The tectonics of the PBMT Terrane are poorly known. The Atrato basin is a synclinorium with a thick sedimentary sequence filled with more than 6000 metres of Late Cretaceous to Pliocene marine sediments. There is an important regional unconformity between the Middle and Late Miocene strata. The basin may correspond to a fore-are or back-are basin active during the formation of the Mande are, which is composed of high-K, basic to intermediate rocks of Tertiary age. These are associated with the large Mandé Batholith, which, with its associated porphyries has been dated radiometrically as Eocene to Oligocene.

The Serranía de Baudó is a little-known region where mafic rocks predominate. Radiometric ages of tholeiitic basalts range from Late Cretaceous to Tertiary. Intercalated sediments have yielded Late Paleocene to Early Miocene faunas, and mid-Miocene algal limestones are intruded by basalts. Chemical analyses of the basalts correspond either to oceanic crust or an immature island are (Goossens et al., 1977). The structures in Baudó seem to correspond to the uplift of oceanic crust related to an accretion prism of the Nazca subduction. If so they represent a post-Miocene geomorphological feature.

The suture between the PBMT and the WAT would have formed before $10 \mathrm{Ma}$ ago, for basic volcanic rocks that seem to cut the suture have been dated at this age. Also, Late Miocene and Quaternary sedimentary rocks cover the suture in the Uraba Gulf to the north and the Buenaventura Bay to the south (Fig. 1).

\section{Suture Between the Autochthonous Block and the EAT}

The Paleozoic to early Mesozoic history of the autochthonous block is fundamentally different from that of the EAT. Only Late Jurassic and Cretaceous events are common to both blocks, so suturing probably took place at some time during or before Jurassic times.

The limit between the autochthon and the EAT is marked by the Guaicaramo fault system, which during late Cenozoic times was the locus for overthrusting of the Eastern Cordillera on the Llanos with a dextral lateral component, especially south of the Garzon Massif (Figs. 1, 4 and 5),

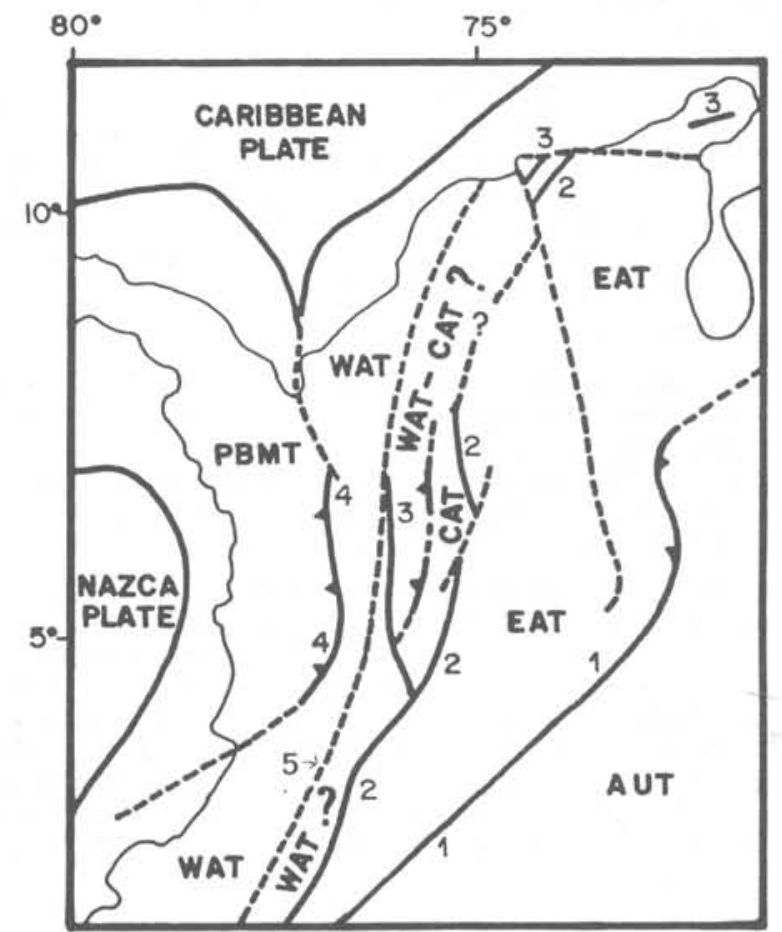

Figure 4: Schematic map of the allochthonous terranes of the Colombian Andes. 1: Guaicaramo suture, 2: Otu-Pericos suture, 3: Overthrusting front of the WAT on the CAT, 4: Dabeiba suture, 5: Cauca-Romeral Fault System. PBMT: Panamá-Baudó-Mandé Terrane, AUT: Autochthonous Block. 
These movements mask the important pre-Cretaceous displacements that accomplished the suturing of the EAT to the autochthon. The EAT may well have been formed more to the north, as indicated by the similarity of Devonian fauna to the Old World Province (Forero, 1986), and then displaced southward along transcurrent faults, which could have been transforms related to the opening of the Caribbean.
Suture Between the PBMT and the WAT

These two terranes are formed by similar materials, although the PBMT has a more mature island arc aspect than recognizable in the WAT. Although the location of the suture between these terranes has been generally placed at the Atrato basin (Case et al., 1971; Pindell and Dewey, 1982; Etayo-Serna et al., 1983), recent studies indicate that it should be drawn along the western flank of the Western w

BAUDO
WESTERN CORDILLERA
CENTRAL CORDILLFRA VALLEY

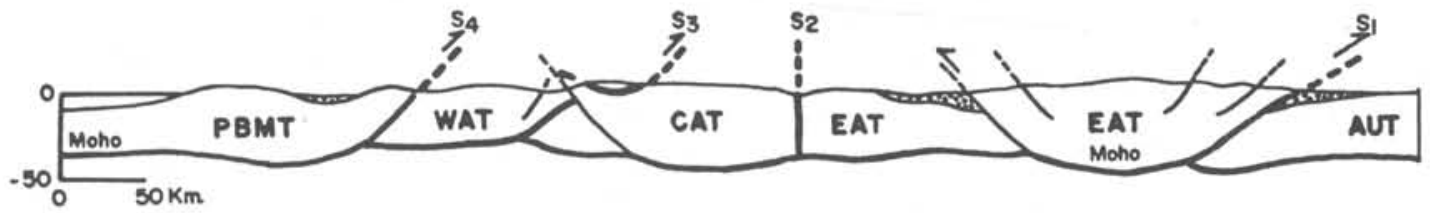

Figure 5: Section across the Colombian Andes at about $6^{\circ} \mathrm{N}$. $S_{1}$ : Guaicaramo suture, $S_{2}$ : otú-Pericos suture, $S_{3}$ : Overthrusting front of the WAT on the CAT, $S_{4}$ : Dabeiba suture. Light stipple - main Tertiary sedimentary basins.

\section{The CAT-EAT Suture}

The Paleozoic histories of the CAT and the EAT are differentiated on the basis of the timing of tectonometamorphic events. In the EAT these are pre-Devonian, whereas in the CAT important Devonian and Permian-Triassic metamorphic events took place. Also, in the EAT magmatism was widespread during early Mesozoic times, but practically absent from the CAT.

The limit between the two terranes is marked by the Otú Fault, which continues to the south as the Pericos fault (Fig. 4). The former displaces Cretaceous sediments a distance of $69 \mathrm{~km}$ in a left lateral sense, but in our opinion this displacement corresponds only to Late CretaceousEarly Tertiary movements. Early movements could have been of the order of hundreds of kilometres, for no correlatable pre-Cretaceous lithological units have been found on both sides of the suture (Figs. 4 and 5). The original place of formation of the CAT is therefore unknown.

\section{The WAT-CAT Suture}

The differences between these two terranes are fundamental. While the CAT represents a polymetamorphic basement, primarily of Paleozoic age, the WAT is composed exclusively of Late Jurassic(?) to Cretaceouse oceanic rocks such as oceanic crust and immature island arcs, represented in part by their metamorphosed equivalents.

The suture between these terranes is marked in the northern part of the Central Cordillera by the easterly thrusting of WAT oceanic materials over the CAT metamorphic basement. The overthrusted materials are not only ophiolites but also medium to high pressure metamorphic rocks of Cretaceous age. That the suturing took place in mid-Cretaceous times is shown by the occurrence on both blocks of Albian lithological units affected by the collision and by the intrusion across the suture of the Late Cretaceous Antioquian Batholith.

In the central and northern parts of the Colombian Andes, lithological units of the WAT are almost in contact with those of the EAT, and it is not known if the CAT is absent or is tectonically buried under the WAT. The "collage" between these terranes probably occurred in several phases, with a late Albian obduction followed by a second one during Senonian times (Bourgois et al., 1982). The emplacement of the WAT is probably related to the closure of the Tethys Sea during Cretaceous and early Tertiary times.
Cordillera (Fig. 4, and see Duque-Caro, 1985; Toussaint and Restrepo, 1986). The suture appears to be represented by thrusting to the east of the PBMT over the western part of the WAT during mid-Miocene times.

The gravity high located along the western flank of the Western Cordillera would thus be due to the tectonic uplift of the Mande arc during the collision, which also affected other features of the Northern Andes. Important tectonic movements affected the Cauca and Magdalena valleys, with the folding of the sediments and the remobilization of faults. The latter includes the left-lateral Cauca-Romeral wrench-fault system and the thrusting of the Eastern Cordillera over the Magdalena Valley to the west and over the Llanos to the east (Figs. 4 and 5). The PBMT probably formed to the west or northwest of its present position, having collided with South America during Miocene times, closing the Caribbean Sea on its western side.

\section{Conclusion}

The Colombian Andes comprise a collage of several allochthonous terranes that have been sutured at different times to the northwestern border of the Guiana Shield. The pre-Cretaceous terranes constitute the continental basement of the eastern part of the Andes, whereas the Cretaceous and Tertiary terranes are formed of oceanic rocks. The terranes with continental crust seem to have moved along $\mathrm{N}-\mathrm{S}$ transcurrent faults that transported exotic blocks from the Caledonian and Hercynian chains, probably from North America or Europe. These megafaults could correspond to transform faults related to the opening of the Caribbean in early Mesozoic times.

In contrast, the suturing of the WAT changed drastically the history of the Colombian Andes with the accretion of oceanic crust and island ares to the continent. This characteristic of the Northern Andes stands in contrast to the Central Andes where these rocks are absent. These accretions took place by a combination of obduction (in particular of the WAT over the CAT in the northern part), imbrications and jumps to the west of the subduction zone in the southern part. In this way, a part of the Tethys was trapped on the northwestern border of South America.

The PBMT corresponds mainly to an ensimatic magmatic arc and represents a Pacific and Central America influence on Colombian geological history. This terrane was formed originally to the west of its present position, having been transported by a dextral displacement in relation to South America. The collision of the southern part of the arc took place by an overthrusting of the PBMT on the WAT during Miocene times, producing a substantial shortening of the Colombian Andes, including the Eastern Cordillera, and accounting for the majority of the neotectonic features of this zone. 
Allochthonous terranes are represented by the oceanic crustal blocks of western Colombia and the Eastern Andean blocks with continental crust; these are allochthonous with respect to the Guiana Shield. The metamorphic rocks of the Eastern and Central Cordillera can, thus, no longer be interpreted as representing the western border of the Guiana Shield.

Prof. J.J. Restrepo teaches geology at the Universidad $\mathrm{Nacional}$ de Colombia, Seccional Medellín (A.A. 3840, Medellín, Colombia). His main field of interest is the history of metamorphic belts in the Central Cordillera of Colombia.

Dr. J.F. Toussaint is also Professor of Geology at the Universidad Nacional de Colombia, Seccional Medellin. He has been working on the structural evolution of the Columbian Andes and especially the Northwestern Andes.
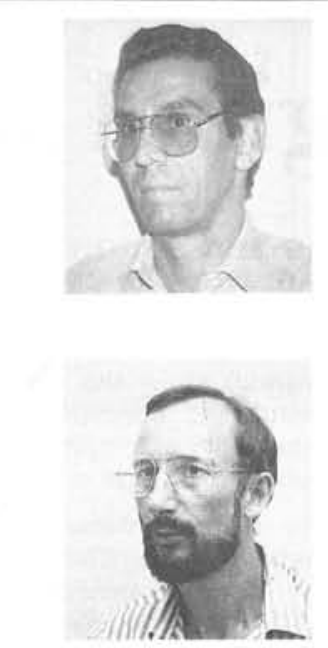

\section{References}

Aspden, J.A. and MeCourt, W.J., 1985. A middle Mesozoic Oceanic Terrane in the Central Cordillera of Western Colombia. Geología Norandina, Bogotá, no. 9, p. 19-26.

Bermúdez Gomez, A., Acosta Negret, R. and Garzón Botero, M., 1985. Republica de Colombia: Mapa Gravimétrico de Anomalías Simples de Bouguer de Colombia. Publicaciones geológicas especiales del Ingeominas, no. 14, Bogotá, Scale $1: 1,000,000$.

Bourgois, J., Calle, B., Tournon, J. and Toussaint, J.F., 1982. The Andean ophiolitic megastructures on the BugaBuenaventura transverse (Western Cordillera-Valle, Colombia). Tectonophysics, v. 82 , no. 3-4, p. 207-229.

Case, J.E. Durán, L.G., López, A. and Moore, W.R., 1971. Tectonic Investigations in Western Colombia and Eastern Panama. Geological Society of America Bulletin, v. 82, no. 10, p. 2685-2712.

Duque-Caro, H., 1985. La cuenca del Atrato en el bloque del Chocó (Sur-américa Noroccidental) y sus implicaciones estratigráficas y estructurales. (Abstract), VI Congreso Latinoamericano de Geología. Bogotá, Colombia. Memorias, v. 6 , no. 1 , p. 50-51.

Etayo-Serna, F. et al., 1983. Mapa de Terrenos Geológicos de Colombia. Publicaciones Geológicas Especiales del Ingeominas, v. 14, p. 1-235.

Flueh, E.R. et al., 1981. Seismic refraction observations in Northwestern Colombia at latitude $5.5^{\circ} \mathrm{N}$. Zentralblatt für Geologie und Palaeontologie, part 1, v. 3-4, p. 231-224.

Forero, A., 1986. Remanentes de la Provincia Paleobiogeográfica Frasniano-Fameniana del Viejo Mundo en los Andes Septentrionales. Geologia Norandina, Bogotá, no. 10, p. $35-38$.

Goossens, P.J., Rose, W.I. and Flores, D., 1977. Geochemistry of tholeiites of the Basic Igneous Complex of Northwestern South America. Geological Society of America Bulletin, v. 88 , no. 12, p. 1711-1720.
Pindell, J. and Dewey, J.F., 1982. Permo-Triassic reconstruction of western Pangea and the evolution of the Gulf of Mexico/Caribbean area. Tectonics, v. 1, no. 2, p. 179-212.

Restrepo, J.J. and Toussaint, J.F., 1974. Obducción cretácea en el Occidente Colombiano. Publicación Especial Geología, Universidad Nacional, Medellín, no. 3, p. 1-26.

Restrepo, J.J. and Toussaint, J.F., 1982. Metamorfismos superpuestos en la Cordillera Central de Colombia. V Congreso Latinoamericano de Geologia, Argentina, v. 3, p. 505-512.

Toussaint, J.F. and Restrepo, J.J., 1986. Límites de placas y acortamientos recientes entre los paralelos $5^{\circ} \mathrm{N}$ y $8^{\circ} \mathrm{N}-$ Andes Colombianos. Symposium Megafaults of South America, San Juan, Argentina, p. 1-8.

Toussaint, J.F., Mercado, M. and Restrepo, J.J., 1987. Megafallas del Noroccidente Suramericano. Publicación Especial ICNE, Universidad Nacional, Medellín, no. 10, p. 1-13.

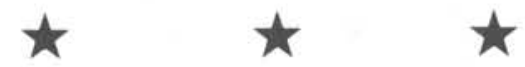

JUST RELEASED

IUGS PUBLICATION NO. 26

THE ORDOVICIAN SYSTEM IN MOST OF RUSSIAN ASIA

The Siberian Platform, by A.V. Kanygin, T.A. Moskalenko and A.G. Yadrenkina;

Taimyr, by L.V. Kekhorosheva, R.F. Sobolevskaya and V.I. Bondarev;

Western Altai-Sayan Folded Region, by A.V. Sennifov, Z.E. Petrunina, E.A. Yolkin and A.M. Obut;

Northeastern and Far Eastern U.S.S.R., by M.M. Oradovskaya.

Contains Correlation Charts and Explanatory Notes, along with 4 figures and 4 plates in pocket. 115 pages, 1988. ISBN 0-930423-15-1.

Price: $\$ 18.00$ (US), including surface postage. For air mail add $\$ 2$ (US) within North America and $\$ 3$ (US) elsewhere. Payments are to be drawn on a Canadian or US bank and made payable to Episodes. Payment may also be made by credit card.

Order from:

$$
\begin{aligned}
& \text { Episodes } \\
& \text { Room } 177,601 \text { Booth Street } \\
& \text { Ottawa, Ontario } \\
& \text { CANADA K1A OE8. }
\end{aligned}
$$

Copies may also be purchased from the IUGS Secretariat, P.0.Box 3006, N-7002 Trondheim, Norway; from the IUGS Liaison office, 103 rue de Lille, 75007 Paris, France; and (in roubles) from the U.S.S.R. National Committee of Geologists, Pyzhevsky 7, 109017 Moscow Zh-17. 